\title{
OPEN Integrative network analyses of transcriptomics data reveal potential drug targets for acute radiation syndrome
}

\author{
Robert Moore ${ }^{1,5}$, Bhanwar Lal Puniya ${ }^{1,5}$, Robert Powers' ${ }^{2}$, Chittibabu Guda ${ }^{3}$, \\ Kenneth W. Bayles ${ }^{4}$, David B. Berkowitz ${ }^{2}$ \& Tomáš Helikar ${ }^{1 \bowtie}$
}

Recent political unrest has highlighted the importance of understanding the short- and long-term effects of gamma-radiation exposure on human health and survivability. In this regard, effective treatment for acute radiation syndrome (ARS) is a necessity in cases of nuclear disasters. Here, we propose 20 therapeutic targets for ARS identified using a systematic approach that integrates gene coexpression networks obtained under radiation treatment in humans and mice, drug databases, disease-gene association, radiation-induced differential gene expression, and literature mining. By selecting gene targets with existing drugs, we identified potential candidates for drug repurposing. Eight of these genes (BRD4, NFKBIA, CDKN1A, TFPI, MMP9, CBR1, ZAP70, IDH3B) were confirmed through literature to have shown radioprotective effect upon perturbation. This study provided a new perspective for the treatment of ARS using systems-level gene associations integrated with multiple biological information. The identified genes might provide high confidence drug target candidates for potential drug repurposing for ARS.

Given the increased capacity of countries to produce enormous radioactive catastrophe and the heightened tensions within the political climate, treatment, and prevention of Acute Radiation Syndrome (ARS) is paramount. ARS is an understudied disease that describes whole body exposure to high doses of radiation ( $>0.7$ Gy) in a short period of time ${ }^{1}$. The pathophysiology of ARS is characterized by nausea, vomiting, and diarrhea ${ }^{1}$. Additionally, exposure of (0.7-2 Gy) irradiation leads to a depletion of lymphocytes, granulocytes, and hepatocytes ${ }^{1,2}$. The progression of the disease generally follows through three clinically distinct phases. Nausea, headaches, diarrhea, fever, altered consciousness, and fatigue characterize the potential outcomes of the initial-prodromalresponse phase ${ }^{2}$. During the second, latent phase, the patient displays no symptoms of ARS. The third stage is the manifest illness phase, where the symptoms of ARS become apparent. There are currently three existing FDA approved treatments for ARS Neupogen, Neulasta, and Leukine ${ }^{3}$. However, these approved drugs are not perfect. Additional treatment options show some disease-mitigating properties. For instance, the treatment of mice by captopril, an angiotensin-converting enzyme (ACE) inhibitor, showed increased survival at thirty days post whole body irradiation ${ }^{4}$. Additional studies have shown the efficacy of Insulin-Like Growth factor 1 in mitigating the deleterious effects of radiation on mice populations ${ }^{5}$. However, these treatment methods only address symptoms of ARS and require strict dosing protocols to acquire adequate efficacy. Thus, additional treatment options are necessary to more effectively challenge ARS.

However, ARS is an understudied disease, and the discovery of new treatments faces significant combinatorial complexity. To deal with this complexity new treatment options can be elucidated using systems- and networkbased approaches that can help identify critical regulatory genes within the disease state. Weighted Gene Coexpression Network Analysis (WGCNA) ${ }^{6}$ can be used to characterize modules of correlated genes in gene regulatory networks. Genes in these modules have high levels of coexpression with a central eigen gene, which represents the first principal component of a given module. The central eigen genes have been found to be highly correlated to the most connected genes within a module called hubs whose expression levels are representative of highly

\footnotetext{
${ }^{1}$ Department of Biochemistry, University of Nebraska-Lincoln, Lincoln, NE, USA. ${ }^{2}$ Department of Chemistry, University of Nebraska-Lincoln, Lincoln, NE, USA. ${ }^{3}$ Department of Genetics, Cell Biology \& Anatomy, University of Nebraska Medical Center, Omaha, NE, USA. ${ }^{4}$ Department of Pathology and Microbiology, University of Nebraska Medical Center, Omaha, NE, USA. ${ }^{5}$ These authors contributed equally: Robert Moore and Bhanwar Lal Puniya. ${ }^{\square}$ email: thelikar2@unl.edu
} 
Collected Datasets from online repository

(GEO)
Filtered datasets and samples based on statistical analysis and physiological states

Calculated gene intramodular connectivity

Constructed Weighted Gene Coexpression Networks

Curated results using consistently differentially expressed genes

$$
\downarrow
$$

Searched the literature to validate curated targets

Figure 1. General workflow to construct gene coexpression network to predict potential drug targets.

correlated genes in the same module. These hub genes can be predictive of novel drug targets. For example, such analyses have been used to characterize genes and pathways associated with Alzheimer's disease ${ }^{7}$, Schizophrenia ${ }^{8}$, Amyotrophic Lateral Sclerosis ${ }^{9}$, diabetic kidney disease ${ }^{10}$, and to determine potential drug targets in pathogens ${ }^{11}$, and other complex human diseases ${ }^{12}$.

To further address challenges with the discovery and development of treatments for complex diseases, repurposing of existing drugs to new diseases has become a preferred alternative to elucidating novel drugs due to high attrition rate and time. For instance, the FDA-approved radiation countermeasures Neupogen (CSF3R), Neulasta (CSF3R), and Leukine (CSF2RA) are repurposed drugs ${ }^{3}$. Neupogen and Neulasta are used in chemotherapyinduced neutropenia and Leukine is used in bone marrow transplant recipients ${ }^{13}$.

In this study, we used a network-based systems analysis of five transcriptomics datasets obtained under radiation treatment and integrated them with public drug information and disease association. This led us to predict eight targets with repurposable drugs/compounds available.

\section{Results}

The workflow used to identify drug targets for ARS is shown in Fig. 1. First, we collected ARS relevant data from public repositories. Second, we constructed gene coexpression networks from transcriptomics data across different species. We used them to identify important genes (hub genes). In the absence of relevant and highquality human data, we aimed to identify consensus across the available ARS transcriptomics data for different species to maximize the quality of predictions. Using a consensus method increases the likelihood that efficacy in a mouse model would also be observed in human trials, which may minimize the drug development costs. Next, to predict potential drug targets for ARS, these hub genes were mapped with external databases of drugs and diseases, differentially expressed genes under radiation treatments from $6 \mathrm{~h}$ to 7 days following radiation of 0.5-10 Gy (different doses and time). The human samples were selected from pre and post-irradiation subjects. These subjects received total body irradiation (TBI) prior to various transplantations. Finally, using literature mining, we predicted the drug targets for ARS.

Weighted gene coexpression network analysis revealed salient expression networks. We collected five transcriptomics datasets relevant to ARS that were obtained from mice and humans from the GEO database. Using these five datasets, we constructed five weighted gene coexpression networks. A minimum of 28 


\begin{tabular}{|l|l|l|l|l|}
\hline Species & Dataset & Number of samples & Total number of modules (sub-networks) & Total number of genes \\
\hline \multirow{3}{*}{ Mouse } & GSE104121 & 48 & 5 & 18,167 \\
\cline { 2 - 6 } & GSE6874 & 28 & 10 & 11,670 \\
\cline { 2 - 6 } & GSE10640 & 169 & 22 & 14,835 \\
\hline \multirow{2}{*}{ Human } & GSE6874 & 70 & 8 & 12,845 \\
\cline { 2 - 5 } & GSE10640 & 60 & 23 & 10,918 \\
\hline
\end{tabular}

Table 1. Details of constructed gene coexpression networks under radiation treatments.

A

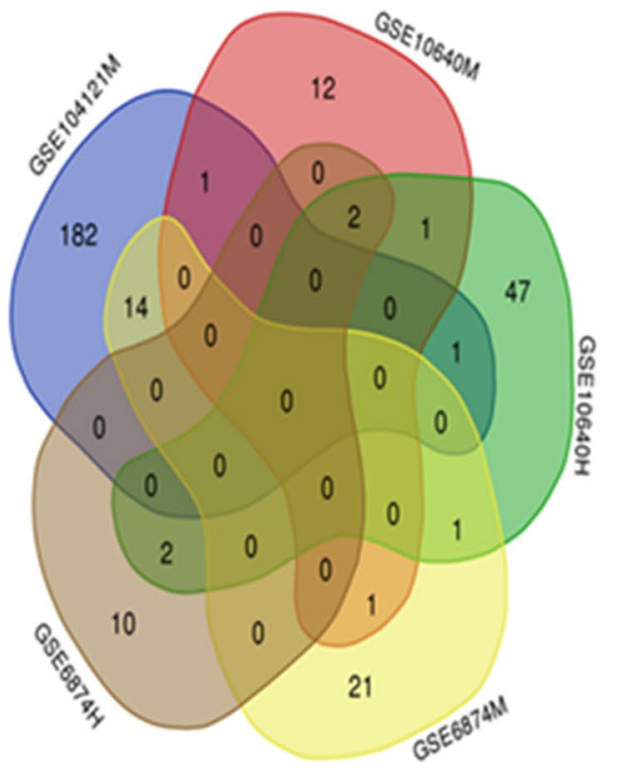

B

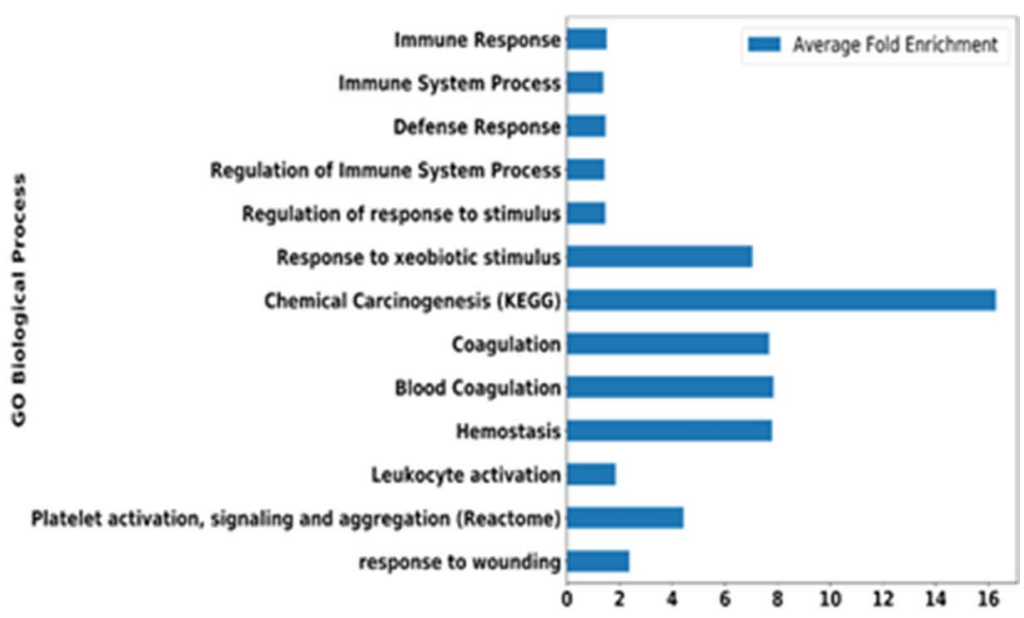

Figure 2. Comparison of enriched biological pathways among different networks. (A) Overlap of the Gene Ontology terms (Biological Processes, Molecular Functions, and Cellular Compartments) and pathways (KEGG pathways, Reactome pathways, BioCyc) in each network based on 5\% False Discovery Rate (FDR). The venn diagram was created using http://bioinformatics.psb.ugent.be/webtools/Venn/14 (B) Average fold enrichment of biological processes and pathways that were enriched in more than one network.

to a maximum of 169 samples was used for network construction (see Materials and methods). The total number of genes included in these datasets were between $\sim 10,000$ to $\sim 18,000$. The scale independence within each network was achieved using a thresholding power $(\beta)$ parameter. Across all networks, the selected $\beta$ was ranging from 3 to 20 (Supplementary Data 1). The number of modules (clusters of genes) identified in each network ranged from 5 to 23 (Table 1). Genes in each module in a particular network have the highest topological overlap (i.e., robust measure than correlation). These genes have significant correlations among expression profiles across different doses of radiation or time points after radiation exposure.

Biological function analysis reveals conserved pathways across networks. In the next step, we found the biological significance of modules identified in the constructed networks. Pathway enrichment analysis showed enrichment with biological processes in at least one module across five datasets (Supplementary Data 2). Next, we identified biological processes that were identified by multiple datasets. Among these, 23 gene ontology (GO), KEGG, and Reactome terms were enriched in more than one dataset (Fig. 2A). These terms included biological processes and pathways related to immune response, xenobiotic stimulus, chemical carcinogenesis, blood coagulation, and white blood cell activation (Fig. 2B) (P-value $<0.05$ and False Discovery Rate $<5 \%$ ). The highest fold enrichment across all the networks (average fold enrichment) was found in chemical carcinogenesis ( $\sim 16$ fold), blood coagulation and hemostasis $(\sim 8$ fold $)$, and response to xenobiotic stimuli $(\sim 7$ fold $)$.

Hub genes found across multiple networks. In the constructed networks, intramodular connectivity was used as a measure to identify hub genes (see Materials and methods). Because of the limited data availability of ARS-relevant human data, we identified hub genes that appeared in multiple datasets as high confidence. To select the top hub genes, first, we used criteria of maximum overlap of hub genes across the different datasets. We identified the top 5, 10, and 20 percent hub genes and compared them across all five datasets. In our analysis, the top $20 \%$ resulted in more hub genes that were overlapped in the maximum number of datasets (Fig. 3A). Among 

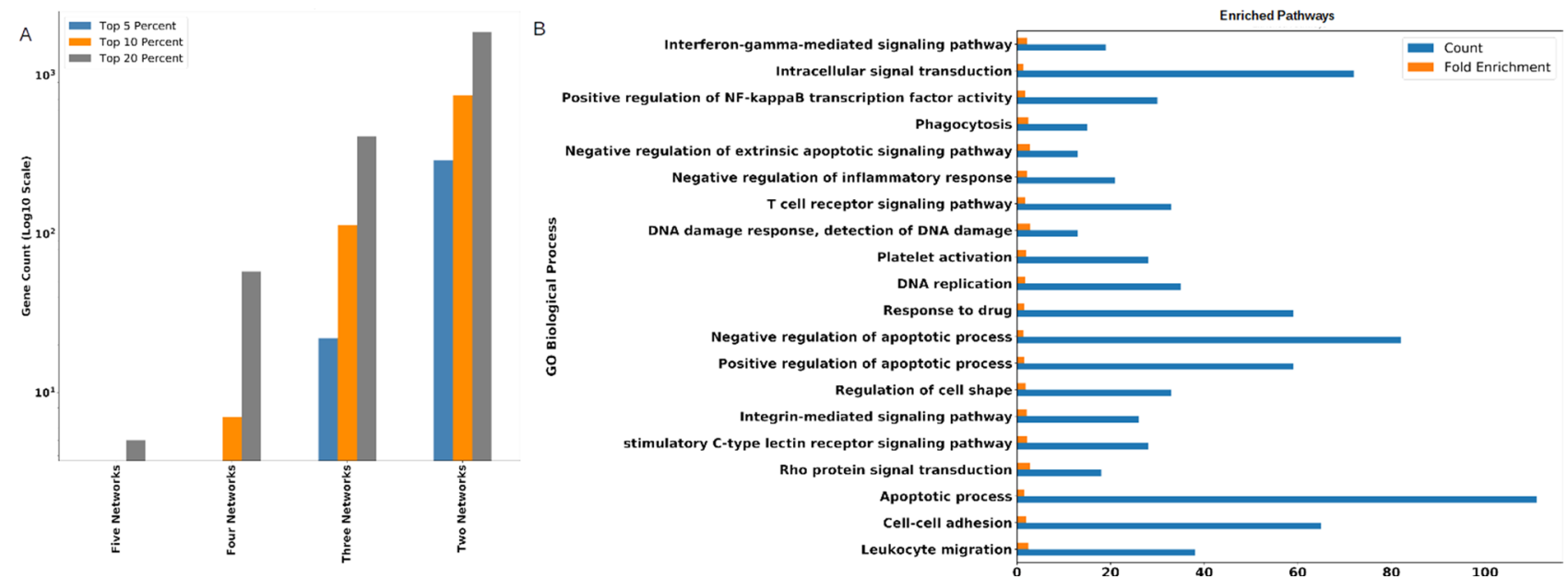

Figure 3. Identification and analysis of hub genes. (A) top 5\%, top 10\%, and top $20 \%$ hub genes identified for each dataset that are identified by five, four, three, and two networks. (B) GO biological processes enriched in 2,351 hub genes with False Discovery Rate $<5 \%$.

these, we found five hub genes (Myeloid Cell Nuclear Differentiation Antigen (MNDA), Syntaxin 11 (STX11), intracellular tyrosine kinase (IKT), Slingshot Protein Phosphatase 2 (SSH2), Keratin 9 (KRT9) ) shared by all networks, 58 hub genes shared by four networks, and 412 hub genes that were shared by three networks. On the contrary, in both the top $5 \%$ and $10 \%$ hub genes, no hub genes were shared by all networks. Four networks shared only seven genes in the top $10 \%$ of hub genes, while not a single hub gen was shared by four out of five networks in the top 5\%. Thus, the top 20\% cutoff allowed optimal comparisons amongst the networks.

Next, among the top 20\% hub genes (Supplementary Data 3), we chose genes that were identified within more than one gene coexpression network. This analysis resulted in 2,351 hub genes identified within at least two coexpression networks (Supplementary Data 3). Enrichment analysis of the selected hub genes showed GO biological processes related to leukocyte migration, apoptosis, DNA replication, T cell signaling, NF- $\kappa \mathrm{B}$, and IFN- $\gamma$ signaling (Fig. 3B).

Furthermore, we have investigated the biological processes that are enriched in differentially expressed in response to high radiation dose (i.e., $10 \mathrm{~Gy}$ ). Many of the biological processes and pathways related to commonly enriched in multiple networks (Fig. 2B) and in hub genes (Fig. 3B) were also enriched in genes upregulated in high radiation doses. We found the gene ontology terms regulation of platelet activation (GO:0,010,543; FDR $=0.035$ ), blood coagulation (GO:0,007,596; FDR $=0.027)$, leukocyte differentiation (GO:0,002,521, $\mathrm{FDR}=0.007)$, response to stimulus (GO:0,050,896; FDR =0.0003), immune systems process (GO:0,002,376, FDR =0.0042), cell-cell adhesion (GO:0,098,609; FDR =0.045), intracellular signal transduction (GO:0,035,556; FDR=0.045), and vesicle-mediated transport (GO:0,016,192; FDR $=0.003$ ) as enriched in consistently upregulated genes (upregulated in more samples than downregulated). A full table of all enriched biological processes is provided as Supplementary Data 4.

Network analysis predicts high confidence drug targets for ARS. To identify drug targets for potential drug repurposing, we identified genes that are targets of existing preclinical and FDA-approved drugs (Materials and methods) and then selected genes that were differentially expressed in response to radiation treatments.

Among the identified 2,351 hub genes, 520 genes were mapped with existing preclinical and approved drugs/compounds (see Materials and Methods). Next, the selected hub genes were compared with differentially expressed genes in ARS across 32 conditions (see Materials and Methods). To validate our findings, first, we investigated already known drug targets for ARS that are part of identified hub genes. The gene target CSF3R of two ARS drugs Neulasta and Neupogen appears in our list and they were differentially expressed in 21 different samples (upregulated in 12 samples and downregulated in 9 samples). Next, we investigated all the hub genes for differential expression. Of the 520 genes with existing drugs, 293 genes were differentially expressed in at least eight (25\%) of 32 conditions (see Supplementary Data 5). Among these, we identified 81 genes that were consistently up-regulated, and 20 genes that were consistently down-regulated (Fig. 4A, Supplementary Data 5). We then analyzed these 101 differentially expressed hub genes with existing drugs and compounds. These genes include 75 genes involved in (based on Gene Ontology) metabolic processes, 59 genes in response to a stimulus, 30 genes in immune system processes, 5 genes in cell population and proliferation, and 4 genes in cell signaling (Fig. 4B).

Next, literature mining revealed that 20 (of 101) genes were relevant to the ARS (Table 2). Of these 20 genes, we identified eight genes whose response to radiation was incongruent with prognostic favorability (indicated with bold font in Table 2): Bromodomain-Containing Protein 4 (BRD4), NF-kB Inhibitor Alpha (NFKBIA)), Cyclin-Dependent Kinase Inhibitor 1A (CDKN1A), Tissue Factor Pathway Inhibitor (TFPI), Matrix Metallopeptidase 9 (MMP9), Carbonyl Reductase 1 (CBR1), Zeta Chain Of T Cell Receptor Associated Protein Kinase 70 (ZAP70), and Isocitrate Dehydrogenase $(\mathrm{NAD}(+)) 3$ Beta (IDH3B). A drug and protein target map of selected 

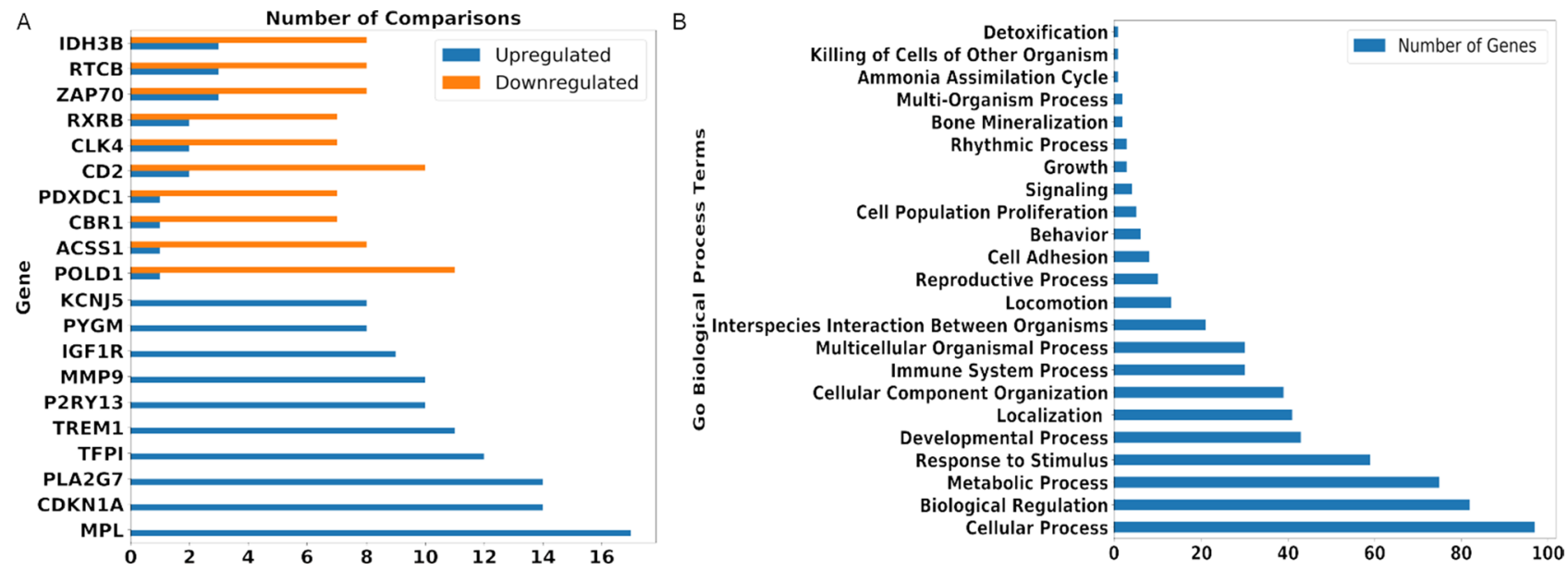

Figure 4. (A) Hub genes found in multiple networks with consistent regulation depicted with the count of samples upregulated/downregulated. (B) Count of genes in GO Biological processes amongst 101 consistently differentially regulated genes.

targets is shown in Fig. 5A. Of 20, 11 genes were also consistently upregulated in response to high radiation doses (10 Gy and 12 Gy) (Fig. 5B).

\section{Discussion}

The onset of Acute Radiation Syndrome (ARS) upon exposure to high doses of radiation in a short period is a burgeoning problem as access to highly radioactive substances becomes ubiquitous. Thus, the importance of characterizing and treating this disease is an emerging endeavor. As such, we created gene correlation networks to help identify hub genes across multiple transcriptomic data for ARS to identify potential therapeutic options. Our transcriptomics-based gene networks were enriched with biological processes, including immune response and immune system process that were supported by another study ${ }^{40}$. While this study provided an overview of potential treatments for ARS there were significant limitations. The use of multiple species, multiple time points and multiple radiation doses means our predictions are a holistic screening of potential treatments for ARS. Within the immune response, pathways related to Blood Coagulation and platelet activation, signaling and aggregation were enriched processes in the networks. It has been shown previously that coagulopathy and lower platelet counts are physiologically-relevant symptoms of acute radiation ${ }^{32}$. Identification of genes that have been independently shown as relevant to ARS provides partial validation to the constructed networks. Evidence was found for eight hub genes identified as potential targets (BRD4, NFKBIA, CDKN1A, TFPI, MMP9, CBR1, ZAP70, IDH3B), that altering their expression may induce radioprotective effects. These eight genes and associated drugs that have the potential for repurposing are discussed below.

Upregulated genes. Bromodomain-Containing Protein 4 (BRD4): BRD4 Inhibition was shown to condense chromatin structure and decrease the DNA damage signaling pathway resulting in less DNA repair. Further, inhibition of BRD4 demonstrated a relaxation of the chromatin structure and more repair signalling ${ }^{17}$. Thus, inhibition of BRD4 using CPI-0610, a phase two clinical trial molecule, could result in a better prognosis for ARS patients. NF-kB inhibitor alpha (NFKBIA): NF-kB inhibition has been shown to increase apoptosis through the loss of regulation of the JNK pathway ${ }^{22}$. Additionally, increased apoptotic activity is induced by irradiation $^{41}$. Thus inhibition of NFKBIA by Acetylsalicylic acid could increase NF-kB activity and confer an antiapoptotic state for the irradiated cells. Cyclin-dependent kinase inhibitor alpha (CDKN1A): It has been shown that active and overexpressed CDKN1A increases cell cycle arrest in the G1 phase ${ }^{29}$. Arrest in this phase of the cell cycle was seen in irradiated cells, and cell cycle arrest is a known promoter of apoptosis ${ }^{30}$. A preclinical compound GGTI-298 is under investigation that can inhibit CDKN1A. Tissue Factor Pathway inhibitor (TFPI): It has been shown that inhibition of TFPI reduces hemophilia bleeding through activating coagulation pathways ${ }^{31}$. Since hemophilia is an indication of Radiation-Induced Disseminated Intravascular Coagulopathy (RDIC) that fresh frozen plasma, platelets or cryoprecipitated antihemophilic factor (AHF) ${ }^{30}$. It is possible that inhibition of TFPI or its combination with human derived products such as AHF may improve the patients' outcome by mitigating the effects of hemophilia in ARS. FDA-approved drug, dalteparin, is an inhibitor available for TFPI. Matrix Metallopeptidase 9 (MMP9): has been suggested to increase fibrosis following damage ${ }^{42}$; fibrosis is increased in cells that receive ionizing radiation ${ }^{43}$. Additionally, captopril is an FDA-approved and known inhibitor of MMP9 $^{13}$ that improves the survival of mice when exposed to high doses of radiation ${ }^{33}$. This protection was highly dependent on the timing of the treatment and suggests further time based inquiries of the data may elucidate time dependent physiological manifestations of ARS.

Downregulated genes. Carbonyl Reductase 1 (CBR1) encodes a protein that reduces the level of reactive oxygen species, especially lipid aldehydes. Further, it has been shown that CBR1 confers radioprotectivity to 


\begin{tabular}{|c|c|c|c|c|c|c|c|c|c|}
\hline Gene name & Protein name & Gene Function $^{\mathrm{a}}$ & Drug bank & $\begin{array}{l}\text { CMAP drug/ } \\
\text { compound }\end{array}$ & $\begin{array}{l}\text { Involvement In } \\
\text { disease }\end{array}$ & $\begin{array}{l}\text { Type of } \\
\text { regulation }\end{array}$ & $\begin{array}{l}\text { Literature } \\
\text { support }\end{array}$ & $\begin{array}{l}\text { Predicted } \\
\text { regulation for } \\
\text { treatment ARS }\end{array}$ & Status of drug \\
\hline MYD88 & $\begin{array}{l}\text { Innate Immune } \\
\text { Signal Transduc- } \\
\text { tion Adaptor }\end{array}$ & \begin{tabular}{|l|} 
Adapter protein \\
involved in \\
the Toll-like \\
receptor and \\
IL-1 receptor \\
signaling \\
pathway in the \\
innate immune \\
response \\
\end{tabular} & & ST-2825 & $\begin{array}{l}\text { MYD88 defi- } \\
\text { ciency }\end{array}$ & Up & \begin{tabular}{|l|} 
MyD88 may \\
protect against \\
long term dam- \\
age and fibrosis \\
following radia- \\
tion injury ${ }^{16}$
\end{tabular} & Activation & $\begin{array}{l}\text { Discovery and } \\
\text { Development }\end{array}$ \\
\hline BRD4 & $\begin{array}{l}\text { Bromodomain- } \\
\text { Containing } \\
\text { Protein } 4\end{array}$ & \begin{tabular}{|l|} 
Chromatin \\
reader protein \\
that recognizes \\
and binds acety- \\
lated histones \\
and plays a \\
key role in the \\
transmission \\
of epigenetic \\
memory across \\
cell divisions \\
and transcrip- \\
tion regulation. \\
Remains associ- \\
ated with acety- \\
lated chromatin \\
throughout the \\
entire cell cycle \\
and provides \\
epigenetic \\
memory for \\
postmitotic G1 \\
gene transcrip- \\
tion by preserv- \\
ing acetylated \\
chromatin status \\
and maintaining \\
high-order chro- \\
matin structure \\
\end{tabular} & & CPI-0610 & $\begin{array}{l}\text { A chromosomal } \\
\text { aberration } \\
\text { involving BRD4 } \\
\text { is found in a } \\
\text { rare, aggressive, } \\
\text { and lethal carci- } \\
\text { noma arising in } \\
\text { midline organs } \\
\text { of young people }\end{array}$ & Up & $\begin{array}{l}\text { Inhibition of } \\
\text { BRD4 increases } \\
\text { cancer cell sur- } \\
\text { vival following } \\
\text { irradiation }^{17}\end{array}$ & Inhibition & Phase 2 \\
\hline AURKA & Aurora Kinase A & \begin{tabular}{|l|} 
Mitotic serine/ \\
threonine \\
kinases that \\
contribute to the \\
regulation of cell \\
cycle progres- \\
sion \\
\end{tabular} & AT9283 & & & Up & $\begin{array}{l}\text { Inhibition } \\
\text { of AURKA } \\
\text { increases radio- } \\
\text { sensitivity in } \\
\text { Hepatocellular } \\
\text { Carcinoma }^{18}\end{array}$ & Activation & Phase 2 \\
\hline СКB & $\begin{array}{l}\text { Creatine Kinase } \\
\text { B }\end{array}$ & \begin{tabular}{|l|} 
Reversibly cata- \\
lyzes the transfer \\
of phosphate \\
between ATP \\
and various \\
phosphogens \\
(e.g. creatine \\
phosphate). \\
Creatine kinase \\
isoenzymes \\
play a central \\
role in energy \\
transduction \\
in tissues with \\
large, fluctuating \\
energy demands, \\
such as skeletal \\
muscle, heart, \\
brain and sper- \\
matozoa
\end{tabular} & Creatine & & & Up & $\begin{array}{l}\text { Measured Cre- } \\
\text { atine levels can } \\
\text { give a prognostic } \\
\text { marker for } \\
\text { radiation dose }{ }^{19}\end{array}$ & Activation & Approved \\
\hline NNMT & $\begin{array}{l}\text { Nicotinamide } \\
\text { N-Methyltrans- } \\
\text { ferase }\end{array}$ & \begin{tabular}{|l|} 
Catalyzes the \\
N-methylation \\
of nicotinamide \\
and other pyri- \\
dines to form \\
pyridinium ions. \\
This activity is \\
important for \\
biotransforma- \\
tion of many \\
drugs and \\
xenobiotic \\
compounds
\end{tabular} & Niacin & & & $\mathrm{Up}$ & $\begin{array}{l}\text { Overexpres- } \\
\text { sion of NNMT } \\
\text { protects Mesen- } \\
\text { chymal Cancer } \\
\text { stem cells } \\
\text { from radiation } \\
\text { therapy }^{20}\end{array}$ & Activation & Approved \\
\hline \multicolumn{10}{|l|}{ Continued } \\
\hline
\end{tabular}




\begin{tabular}{|c|c|c|c|c|c|c|c|c|c|}
\hline Gene name & Protein name & Gene Function $^{\mathrm{a}}$ & Drug bank & $\begin{array}{l}\text { CMAP drug/ } \\
\text { compound }\end{array}$ & $\begin{array}{l}\text { Involvement In } \\
\text { disease }\end{array}$ & $\begin{array}{l}\text { Type of } \\
\text { regulation }\end{array}$ & $\begin{array}{l}\text { Literature } \\
\text { support }\end{array}$ & \begin{tabular}{|l} 
Predicted \\
regulation for \\
treatment ARS
\end{tabular} & Status of drug \\
\hline PTPN1 & $\begin{array}{l}\text { Protein Tyrosine } \\
\text { Phosphatase } \\
\text { Non-receptor } \\
\text { Type 1 }\end{array}$ & $\begin{array}{l}\text { Tyrosine-protein } \\
\text { phosphatase } \\
\text { which acts as } \\
\text { a regulator of } \\
\text { endoplasmic } \\
\text { reticulum } \\
\text { unfolded protein } \\
\text { response }\end{array}$ & Tiludronic Acid & Tiludronate & & Up & $\begin{array}{l}\text { Expression } \\
\text { of PTPN1 } \\
\text { improves } \\
\text { survival of irra- } \\
\text { diated mice }\end{array}$ & Activation & Approved \\
\hline NFKBIA & $\begin{array}{l}\text { NF-Kappa-B } \\
\text { Inhibitor Alpha }\end{array}$ & \begin{tabular}{|l|} 
Inhibits the \\
activity of \\
dimeric NF- \\
kappa-B/REL \\
complexes by \\
trapping REL \\
dimers in the \\
cytoplasm \\
through mask- \\
ing of their \\
nuclear localiza- \\
tion signals. \\
On cellular \\
stimulation by \\
immune and \\
proinflamma- \\
tory responses, \\
becomes \\
phosphoryl- \\
ated promoting \\
ubiquitination \\
and degradation, \\
enabling the \\
dimeric RELA \\
to translocate \\
to the nucleus \\
and activate \\
transcription \\
\end{tabular} & $\begin{array}{l}\text { Acetylsalicylic } \\
\text { acid }\end{array}$ & Aspirin & $\begin{array}{l}\text { Ectodermal } \\
\text { dysplasia and } \\
\text { immunodefi- } \\
\text { ciency 2 }\end{array}$ & Up & $\begin{array}{l}\text { Blocking NF-kB } \\
\text { increases } \\
\text { apoptosis } \\
\text { and decrease } \\
\text { in growth in } \\
\text { several cancer }^{\text {lineages }}{ }^{22}\end{array}$ & Inhibition & Approved \\
\hline MCL1 & $\begin{array}{l}\text { MCL1 Apoptosis } \\
\text { Regulator }\end{array}$ & \begin{tabular}{|l|} 
Involved in the \\
regulation of \\
apoptosis versus \\
cell survival, \\
and in the \\
maintenance of \\
viability but not \\
of prolifera- \\
tion. Mediates \\
its effects by \\
interactions with \\
a number of \\
other regulators \\
of apoptosis. Iso- \\
form 1 inhibits \\
apoptosis. Iso- \\
form 2 promotes \\
apoptosis
\end{tabular} & & Rosmarinic-acid & & Up & $\begin{array}{l}\text { MCL1 Protects } \\
\text { against radia- } \\
\text { tion-induced } \\
\text { apoptosis }^{23}\end{array}$ & Activation & Launched \\
\hline ANXA1 & Annexin Al & $\begin{array}{l}\text { Plays important } \\
\text { roles in the } \\
\text { innate immune } \\
\text { response as } \\
\text { an effector of } \\
\text { glucocorticoid- } \\
\text { mediated } \\
\text { responses and } \\
\text { regulator of the } \\
\text { inflammatory } \\
\text { process }\end{array}$ & Amcinonide & Amcinonide & & Up & $\begin{array}{l}\text { ANXA1 serum } \\
\text { concentra- } \\
\text { tion following } \\
\text { glucocorticoid } \\
\text { treatment } \\
\text { improves prog- } \\
\text { nosis following } \\
\text { radiation- } \\
\text { induced lung } \\
\text { injury }{ }^{24}\end{array}$ & Activation & Launched \\
\hline RALB & $\begin{array}{l}\text { RAS like proto- } \\
\text { oncogene }\end{array}$ & \begin{tabular}{|l|} 
Multifunctional \\
GTPase involved \\
in a variety of \\
cellular pro- \\
cesses including \\
gene expression, \\
cell migration, \\
cell prolifera- \\
tion, oncogenic \\
transformation \\
and membrane \\
trafficking
\end{tabular} & & BQU57 & & Up & $\begin{array}{l}\text { RALB confers } \\
\text { radioresistance } \\
\text { to multiple } \\
\text { tumor types }^{25}\end{array}$ & Activation & Preclinical \\
\hline \multicolumn{10}{|l|}{ Continued } \\
\hline
\end{tabular}




\begin{tabular}{|c|c|c|c|c|c|c|c|c|c|}
\hline Gene name & Protein name & Gene Function $^{\mathrm{a}}$ & Drug bank & $\begin{array}{l}\text { CMAP drug/ } \\
\text { compound }\end{array}$ & $\begin{array}{l}\text { Involvement In } \\
\text { disease }\end{array}$ & $\begin{array}{l}\text { Type of } \\
\text { regulation }\end{array}$ & $\begin{array}{l}\text { Literature } \\
\text { support }\end{array}$ & \begin{tabular}{|l|} 
Predicted \\
regulation for \\
treatment ARS
\end{tabular} & Status of drug \\
\hline CBFB & $\begin{array}{l}\text { Core-Binding } \\
\text { Factor Subunit } \\
\text { Beta }\end{array}$ & $\begin{array}{l}\text { Forms the } \\
\text { heterodimeric } \\
\text { complex } \\
\text { core-binding } \\
\text { factor (CBF) } \\
\text { with RUNX } \\
\text { family proteins } \\
\text { (RUNX1, } \\
\text { RUNX2, and } \\
\text { RUNX3) }\end{array}$ & & AL-10-49 & & Up & $\begin{array}{l}\text { Suppresses } \\
\text { Cancer }{ }^{26}\end{array}$ & Activation & Preclinical \\
\hline ANXA2 & Annexin A2 & \begin{tabular}{|l|} 
Calcium- \\
regulated \\
membrane- \\
binding protein \\
whose affinity \\
for calcium is \\
greatly enhanced \\
by anionic \\
phospholipids. \\
It binds two cal- \\
cium ions with \\
high affinity. \\
May be involved \\
in the heat-stress \\
response
\end{tabular} & $\begin{array}{l}\text { Fluocinolone } \\
\text { acetonide }\end{array}$ & & & Up & $\begin{array}{l}\text { Prevents } \\
\text { apoptosis }^{27}\end{array}$ & Activation & Approved \\
\hline MPL & $\begin{array}{l}\text { MPL Proto- } \\
\text { Oncogene, } \\
\text { Thrombopoietin } \\
\text { Receptor }\end{array}$ & \begin{tabular}{|l|} 
Receptor for \\
thrombopoi- \\
etin that acts \\
as a primary \\
regulator of \\
megakaryopoie- \\
sis and platelet \\
production. \\
May represent a \\
regulatory mol- \\
ecule specific for \\
TPO-R-depend- \\
ent immune \\
responses \\
\end{tabular} & Eltrombopag & Avatrombopag & $\begin{array}{l}\text { Congenital } \\
\text { amegakaryo- } \\
\text { cytic thrombo- } \\
\text { cytopenia }\end{array}$ & Up & $\begin{array}{l}\text { c-MPL agonist } \\
\text { confers complete } \\
\text { survival in mice } \\
\text { exposed to ion- } \\
\text { izing radiation }{ }^{28}\end{array}$ & Activation & $\begin{array}{l}\text { Launched, } \\
\text { Launched }\end{array}$ \\
\hline CDKN1A & $\begin{array}{l}\text { Cyclin-Depend- } \\
\text { ent Kinase } \\
\text { Inhibitor 1A }\end{array}$ & \begin{tabular}{|l|} 
May be involved \\
in p53/TP53 \\
mediated inhibi- \\
tion of cellular \\
proliferation \\
in response to \\
DNA damage. \\
Binds to and \\
inhibits cyclin- \\
dependent \\
kinase activity, \\
preventing \\
phosphorylation \\
of critical cyclin- \\
dependent \\
kinase substrates \\
and blocking cell \\
cycle progres- \\
sion
\end{tabular} & & GGTI-298 & & Up & $\begin{array}{l}\text { CDKN1A } \\
\text { is shown to } \\
\text { promote cell } \\
\text { cycle arrest in } \\
\text { G1 phase }{ }^{29} \text {. G1 } \\
\text { phase cell cycle } \\
\text { arrest is seen } \\
\text { in cells with } \\
\text { wild-type p53 } \\
\text { gene following } \\
\text { irradiation }^{30}\end{array}$ & Inhibition & Preclinical \\
\hline TFPI & $\begin{array}{l}\text { Tissue Factor } \\
\text { Pathway Inhibi- } \\
\text { tor }\end{array}$ & \begin{tabular}{|l|} 
Inhibits factor X \\
(X(a)) directly \\
and, in a Xa- \\
dependent way, \\
inhibits VIIa/ \\
tissue factor \\
activity, presum- \\
ably by forming \\
a quaternary \\
Xa/LACI/VIIa/ \\
TF complex. \\
It possesses an \\
antithrombotic \\
action and also \\
the ability to \\
associate with \\
lipoproteins in \\
plasma
\end{tabular} & Dalteparin & Dalteparin & & UP & $\begin{array}{l}\text { TFPI inhibition } \\
\text { can inhibit } \\
\text { hemophilia }^{31} \text {. } \\
\text { Radiation- } \\
\text { induced } \\
\text { coagulopathy } \\
\text { decreases clot- } \\
\text { ting ability }^{32}\end{array}$ & Inhibition & Approved \\
\hline Continued & & & & & & & & & \\
\hline
\end{tabular}




\begin{tabular}{|c|c|c|c|c|c|c|c|c|c|}
\hline Gene name & Protein name & Gene Function ${ }^{\mathrm{a}}$ & Drug bank & $\begin{array}{l}\text { CMAP drug/ } \\
\text { compound }\end{array}$ & $\begin{array}{l}\text { Involvement In } \\
\text { disease }\end{array}$ & $\begin{array}{l}\text { Type of } \\
\text { regulation }\end{array}$ & $\begin{array}{l}\text { Literature } \\
\text { support }\end{array}$ & \begin{tabular}{|l} 
Predicted \\
regulation for \\
treatment ARS
\end{tabular} & Status of drug \\
\hline MMP9 & $\begin{array}{l}\text { Matrix Metal- } \\
\text { lopeptidase } 9\end{array}$ & \begin{tabular}{|l|} 
May play an \\
essential role in \\
local proteolysis \\
of the extracellu- \\
lar matrix and in \\
leukocyte migra- \\
tion. Could play \\
a role in bone \\
osteoclastic \\
resorption. \\
Cleaves KiSS1 \\
at a Gly-|-Leu \\
bond. Cleaves \\
type IV and type \\
V collagen into \\
large C-terminal \\
three quarter \\
fragments \\
and shorter \\
N-terminal one \\
quarter frag- \\
ments. Degrades \\
fibronectin but \\
not laminin or \\
Pz-peptide
\end{tabular} & Captopril & & $\begin{array}{l}\text { Intervertebral } \\
\text { disc disease }\end{array}$ & UP & $\begin{array}{l}\text { Captopril is } \\
\text { an inhibitor of } \\
\text { MMP9 and has } \\
\text { shown increased } \\
\text { survival in mice } \\
\text { depending on } \\
\text { dosage timing } \\
33\end{array}$ & Inhibition & Launched \\
\hline IGF1R & $\begin{array}{l}\text { Insulin-Like } \\
\text { Growth Factor } 1 \\
\text { Receptor }\end{array}$ & \begin{tabular}{|l|} 
Receptor tyros- \\
ine kinase which \\
mediates actions \\
of insulin-like \\
growth factor 1 \\
(IGF1). Binds \\
IGF1 with \\
high affinity \\
and IGF2 and \\
insulin (INS) \\
with a lower \\
affinity. The \\
activated IGF1R \\
is involved in \\
cell growth and \\
survival control. \\
IGF1R is crucial \\
for tumor \\
transformation \\
and survival of \\
malignant cell
\end{tabular} & ATL1101 & & $\begin{array}{l}\text { Insulin-like } \\
\text { growth factor } \\
\text { resistance }\end{array}$ & UP & $\begin{array}{l}\text { Overexpression } \\
\text { of IGF1R is } \\
\text { known to confer } \\
\text { increased radi- } \\
\text { oresistance in } \\
\text { chemotherapy }^{34}\end{array}$ & Activation & Investigational \\
\hline CBR1 & $\begin{array}{l}\text { Carbonyl Reduc- } \\
\text { tase } 1\end{array}$ & \begin{tabular}{|l} 
NADPH- \\
dependent \\
reductase with \\
broad substrate \\
specificity. \\
Catalyzes the \\
reduction of a \\
wide variety of \\
carbonyl com- \\
pounds includ- \\
ing quinones, \\
prostaglandins, \\
menadione, \\
plus various \\
xenobiotics
\end{tabular} & Acetohexamide & & & Down & $\begin{array}{l}\text { Carbonyl } \\
\text { Reductase } \\
\text { confers radio- } \\
\text { protectivity in } \\
\text { head and neck } \\
\text { squamous cell } \\
\text { carcinoma }^{35}\end{array}$ & Activation & Launched \\
\hline ZAP70 & $\begin{array}{l}\text { Zeta Chain of } \\
\text { T Cell Receptor } \\
\text { Associated Pro- } \\
\text { tein Kinase } 70\end{array}$ & \begin{tabular}{|l|} 
Tyrosine kinase \\
that plays an \\
essential role \\
in regulation \\
of the adap- \\
tive immune \\
response. \\
Regulates motil- \\
ity, adhesion and \\
cytokine expres- \\
sion of mature \\
T-cells, as well \\
as thymocyte \\
development. \\
Contributes also \\
to the develop- \\
ment and activa- \\
tion of primary \\
B-lymphocytes
\end{tabular} & Staurosporine & & $\begin{array}{l}\text { Immunodefi- } \\
\text { ciency } 48\end{array}$ & Down & $\begin{array}{l}\text { Zap70 Defi- } \\
\text { ciency leads } \\
\text { to a loss of T } \\
\text { cells }{ }^{36} \text { Radia- } \\
\text { tion induces } \\
\text { lymphopenia }\end{array}$ & Activation & Preclinical \\
\hline \multicolumn{10}{|l|}{ Continued } \\
\hline
\end{tabular}




\begin{tabular}{|c|c|c|c|c|c|c|c|c|c|}
\hline Gene name & Protein name & Gene Function ${ }^{a}$ & Drug bank & $\begin{array}{l}\text { CMAP drug/ } \\
\text { compound }\end{array}$ & $\begin{array}{l}\text { Involvement In } \\
\text { disease }\end{array}$ & $\begin{array}{l}\text { Type of } \\
\text { regulation }\end{array}$ & $\begin{array}{l}\text { Literature } \\
\text { support }\end{array}$ & \begin{tabular}{|l} 
Predicted \\
regulation for \\
treatment ARS
\end{tabular} & Status of drug \\
\hline IDH3B & $\begin{array}{l}\text { Isocitrate } \\
\text { Dehydrogenase } \\
(\mathrm{NAD}(+)) \text { 3 Beta }\end{array}$ & \begin{tabular}{|l|} 
Plays a struc- \\
tural role to \\
facilitate the \\
assembly and \\
ensure the full \\
activity of the \\
enzyme catalyz- \\
ing the decar- \\
boxylation of \\
isocitrate (ICT) \\
into alpha- \\
ketoglutarate
\end{tabular} & NADH & Coenzyme i & $\begin{array}{l}\text { Retinitis Pig- } \\
\text { mentosa }\end{array}$ & Down & $\begin{array}{l}\text { Isocitrate } \\
\text { Dehydroge- } \\
\text { nase generates } \\
\text { NADH. NADH } \\
\text { is radioprotec- } \\
\text { tive for mouse } \\
\text { intestine }^{38}\end{array}$ & Activation & $\begin{array}{l}\text { Approved, } \\
\text { Phase } 2\end{array}$ \\
\hline
\end{tabular}

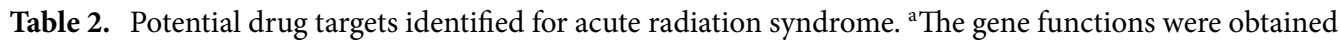
from the Uniprot database ${ }^{39}$.

head and neck squamous cell carcinomas ${ }^{35}$. Thus increasing the activity level of CBR1 may decrease the oxidative stress induced by radiation. FDA-approved acetohexamide currently used to treat type II diabetes can be used as an activator of CBR1. Zeta Chain of T Cell Receptor Associated Protein Kinase 70 (ZAP70) regulates T-cell signaling via interaction with cytoplasmic tyrosine kinases ${ }^{44}$. Loss-of-function in ZAP70 has been shown to lead to a systemic loss of functional $\mathrm{T} \mathrm{cells}^{36}$ in mice post radiation ${ }^{37}$. Thus, we hypothesize that upregulating ZAP70 may lead to regaining functional T cells following radiation. Staurosporine is an experimental drug known to modulate the ZAP70 function and could be further explored as a potential repurposing option for ARS. Finally, Isocitrate Dehydrogenase (NAD(+)) 3 Beta (IDH3B) facilitates the transfer of Hydrogen from Isocitrate to $\mathrm{NAD}(+)$; exogenous $\mathrm{NADH}$ has been shown to protect mice intestines after radiation injury ${ }^{38}$. Thus, we hypothesize that the increase of IDH3B can lead to higher levels of NADH in the system and thus improve the prognosis following radiation injury. The compound coenzyme I (in Phase 2 of clinical trials) is indeed known to interact with IDH3B and could be explored for repurposing in ARS.

In addition to the above-discussed genes, all other reported genes elucidate a physiological state that is induced under various radiation regiments. We predicted the possible activation of 12 other genes that have drugs approved by the FDA or in preclinical and clinical phases. Based on published literature, the activation of these genes may have radioprotective properties, and thus the development of corresponding activators may be useful. These include MYD88 (Myeloid Differentiation Primary Response Protein), which is found as upregulated in response to radiation and has been found to protect against radiation injuries ${ }^{16}$. The upregulation of Aurora Kinase A (AURKA) may also lead to protective properties against radiation as its inhibition has been found to increase radiosensitivity in hepatocellular carcinoma ${ }^{18}$. Similarly, activation of Protein Tyrosine Phosphatase Non-receptor Type 1 (PTPN1) has been found to increase survival in mice after irradiation. Finally, Nicotinamide N-Methyltransferase (NNMT) has been found to protect cancer cells from radiation.

Further delineation based on timing and dose could further specify which treatment and response best suit the target. Additional studies can be conducted to determine the efficacy of modulating these genes individually or in combination. Additionally, the data was garnered primarily from mice which will heavily influence the predicted treatments. Finally, while this modulation can confer protection against acute radiation syndrome, some of these genes can also provide radioprotective properties to tumor cells and hence may not represent a long-term treatment option for patients with ARS.

\section{Conclusions}

This study uses systems-level gene associations integrated with multiple biological information levels and provides a new perspective for the treatment of Acute Radiation Syndrome (ARS). The study identified eight genes with existing drugs and relevance to ARS, which may serve as high confidence drug target candidates for drug repurposing, potentially providing treatment of ARS.

Dataset collection. Gene expression datasets GSE104121 ${ }^{45}$, GSE10640 ${ }^{46}$, and GSE6874 ${ }^{47}$ related to ARS were collected from the GEO database ${ }^{48}$. These datasets were generated from studies using humans and mice. In GSE104121, peripheral whole blood samples were collected from 48 mice following 1-12 Gy total body irradiation (TBI), at $6 \mathrm{~h}, 16 \mathrm{~h}, 24 \mathrm{~h}$, and $48 \mathrm{~h}$ after the treatment. GSE10640 was generated using human and mouse samples. Human data were collected prior to and following the total body irradiation (TBI) of patients with 1.5-2 Gy. From this dataset we used 70 human samples (36 Pre Irradiation 34 post irradiation). These samples came from $6 \mathrm{~h}$ after TBI of 1.5-2.0 Gy in preparation for transplantation. The mouse data were collected following $6 \mathrm{~h}, 24 \mathrm{~h}$, and 7 days of TBI with $0.5,2$, and $10 \mathrm{~Gy}$. GSE6874 consists of two datasets GSE6871 (human) and GSE6873 (mouse). Human data were collected from 60 samples (33 pre-irradiation and 27 post-irradiation) pre- and post-irradiated (with 1.5-2 Gy TBI) patients. Mouse data were collected following TBI varied from 0.5 Gy to 10 Gy.

Differential gene expression analysis. Differential gene expression analysis was conducted for each dataset using limma $a^{49}$ and $a f f y^{50} \mathrm{R} /$ Bioconductor packages. The comparison was made between healthy samples and the various conditions, including radiation dose and time post-irradiation. Additionally, within GSE10640, 
A

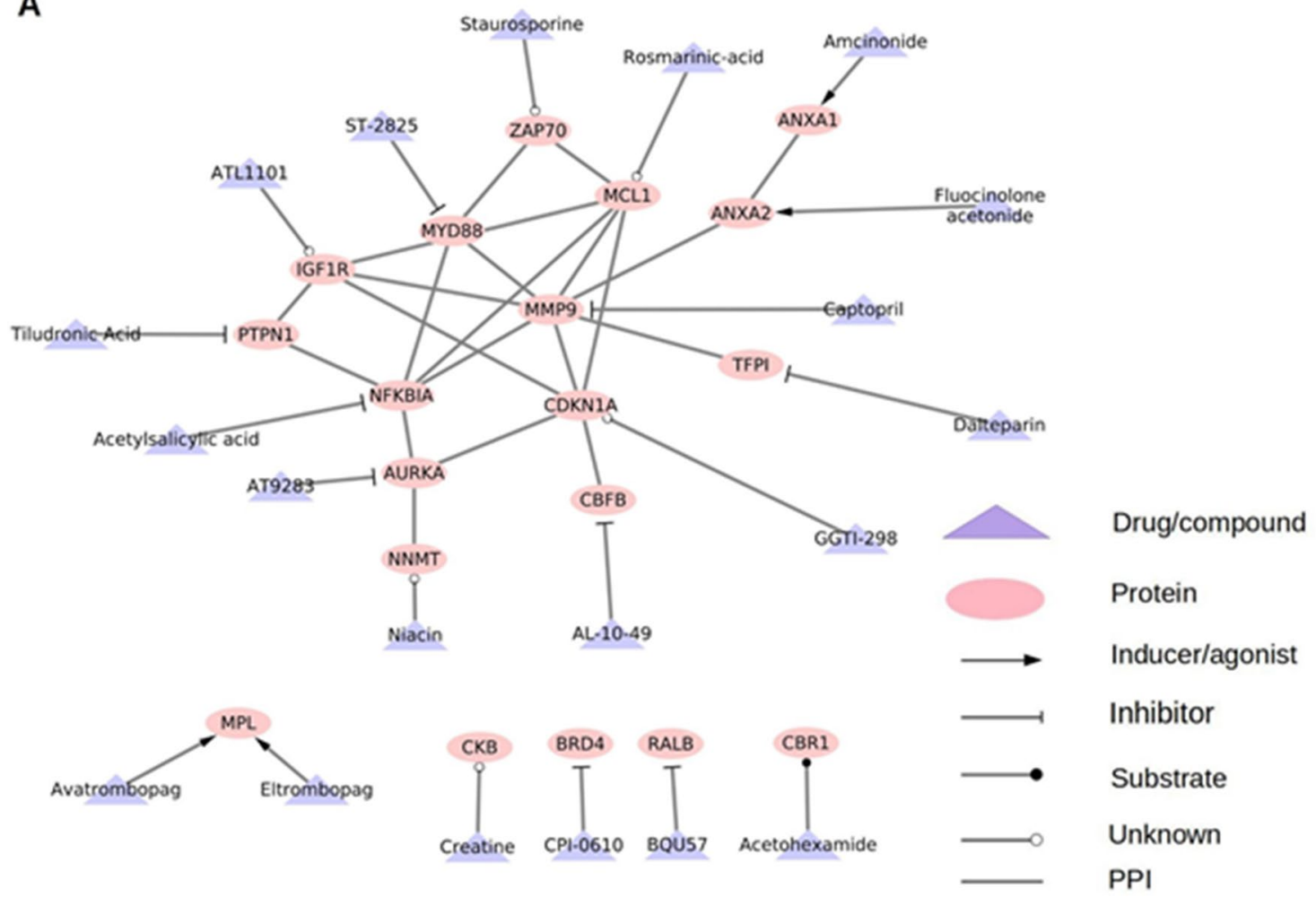

B

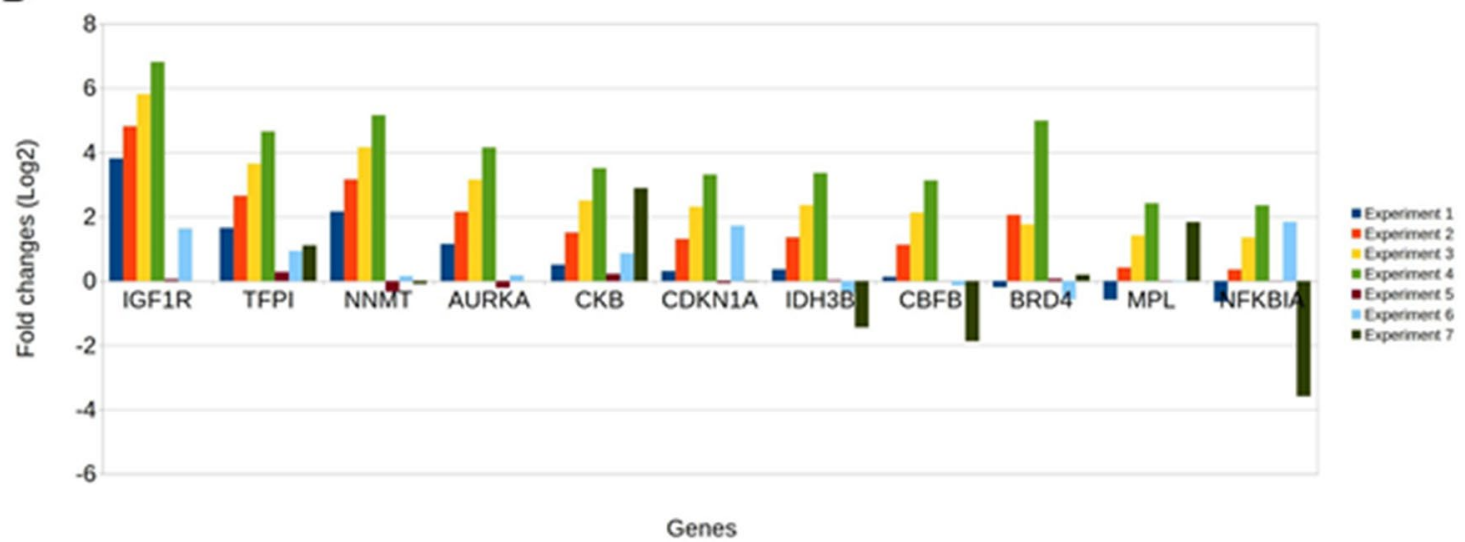

Figure 5. Drug-target network of potential targets and gene expression. (A) drug-target network. $\mathrm{PPI}=$ protein-protein associations obtained using STRING database. The network was created using Cytoscape version 3.7. $2^{15}$. (B) Fold changes of genes showing consistent differential expression of mice in high radiation doses (i.e., $10 \mathrm{~Gy}$ and 12 Gy) from GSE10640, GSE6874, and GSE104121. Experiment 1 and 2 were from BLK mice 24 h post-irradiation with $10 \mathrm{~Gy}$, Experiment 3-6 were from BalbC $(3,5,6)$ and BLK $(4) 6 \mathrm{hrs}$ postirradiation with $10 \mathrm{~Gy}$, and Experiment 7 was performed on BalbC mice 6hrs post-irradiation with $12 \mathrm{~Gy}$.

there were multiple species of mice used (Balbc and Blk); hence, differential expression was performed between healthy Balbc vs. Irradiated and similarly for the Blk mice. A total of 32 comparisons for differential expression analysis were performed across all five datasets (Supplementary Data 5). Two-fold change was considered as a significant differential expression.

Weighted gene coexpression network construction. Prior to the construction of the network, datasets were quantile normalized using the limma package in R. Next, genes were filtered based on the coefficient of variation $(\mathrm{CV})$ to remove spurious correlations among genes. A total of five networks were constructed consisting of two human (one from GSE10640 one from GSE6874), and three mice networks (GSE10640, GSE6874, GSE104121).

Pearson's correlation coefficient between genes within each dataset. Assuming the biological networks show scale-free topology, the absolute correlation between genes was raised with a soft thresholding 
power $(\beta)$ (Supplementary Data 1 ). All networks were fitted using an $\mathrm{R}^{\wedge} 2$ cutoff of $0.80^{6}$. The clustering of genes was performed based on the dissimilarities of genes using topological overlap measure (TOM). Average Linkage Hierarchical clustering was used for module detection in each network ${ }^{6}$.

Hub genes identification. Hub genes were identified in each correlation network characterized by the genes with the highest intramodular connectivity value ${ }^{6}$. This value determines the level of module membership a gene has; thus, a higher value of intramodular connectivity corresponds to more significant connectivity in the module. Genes among the top 20 percent were selected to ensure the highest confidence in the genes selected while simultaneously not introducing false positives by lowering the threshold.

Identification of known drugs and correlation with diseases. To investigate if a hub gene is an existing drug target, we used the repurposing too ${ }^{51}$ in the ConnectivityMap ${ }^{52}$ and DrugBank databases ${ }^{13}$. Additionally, we utilized UniProt ${ }^{39}$ and OMIM databases ${ }^{53}$ to map genes to associated diseases.

Functional enrichment analysis. Gene Ontology (GO) biological processes ${ }^{54}$, KEGG pathways ${ }^{55}$, and Reactome pathways ${ }^{56}$ terms were utilized for enrichment analysis.

Enrichment of genes within each module in the networks was performed using the anRichment ${ }^{57}$ and anRichmentMethods packages in R. Pathways with Benjamini-Hochberg (FDR) value $<0.05$ were considered to be enriched.

A functional analysis of hub genes was performed using DAVID ${ }^{58}$, STRING $^{59}$ and UniProt databases. In the DAVID database and STRING database, biological processes and pathways with FDR $<0.05$ were considered as enriched.

\section{Data availability}

The publicly available datasets analyzed during the current study are available in the Gene Expression Omnibus. GSE10640 for human and mice irradiated PBMCs-https://www.ncbi.nlm.nih.gov/geo/query/acc. cgi?acc=GSE10640. GSE6874 For human and mice irradiated PBMCs—https://www.ncbi.nlm.nih.gov/geo/ query/acc.cgi?acc=GSE6874.

Received: 16 September 2020; Accepted: 17 February 2021

Published online: 10 March 2021

\section{References}

1. CDC Radiation Emergencies | Acute Radiation Syndrome. https://www.cdc.gov/nceh/radiation/emergencies/ars.htm (2019).

2. Macià i Garau, M., Lucas Calduch, A. \& López, E. C. Radiobiology of the acute radiation syndrome. Rep. Pract. Oncol. Radiother. 16, 123-130 (2011).

3. Singh, V. K., Seed, T. M. \& Olabisi, A. O. Drug discovery strategies for acute radiation syndrome. Expert Opin. Drug Discov. 14, $701-715$ (2019).

4. McCart, E. A. et al. Delayed captopril administration mitigates hematopoietic injury in a murine model of total body irradiation. Sci. Rep. 9, 1-13 (2019).

5. Zhou, D. et al. Insulin-like growth factor 1 mitigates hematopoietic toxicity after lethal total body irradiation. Int. J. Radiat. Oncol. Biol. Phys. 85, 1141-1148 (2013).

6. Langfelder, P. \& Horvath, S. WGCNA: an R package for weighted correlation network analysis. BMC Bioinform. 9, 559 (2008).

7. Liang, J.-W. et al. Application of weighted gene co-expression network analysis to explore the key genes in Alzheimer's disease. J. Alzheimers Dis. JAD 65, 1353-1364 (2018).

8. Torkamani, A., Dean, B., Schork, N. J. \& Thomas, E. A. Coexpression network analysis of neural tissue reveals perturbations in developmental processes in schizophrenia. Genome Res. 20, 403-412 (2010).

9. Saris, C. G. et al. Weighted gene co-expression network analysis of the peripheral blood from Amyotrophic Lateral Sclerosis patients. BMC Genomics 10, 405 (2009).

10. Komorowsky, C. V., Brosius, F. C., Pennathur, S. \& Kretzler, M. Perspectives on systems biology applications in diabetic kidney disease. J. Cardiovasc. Transl. Res. 5, 491-508 (2012).

11. Puniya, B. L., Kulshreshtha, D., Verma, S. P., Kumar, S. \& Ramachandran, S. Integrated gene co-expression network analysis in the growth phase of Mycobacterium tuberculosis reveals new potential drug targets. Mol. Biosyst. 9, 2798-2815 (2013).

12. Ivliev, A. E., 't Hoen, P. A. C., Borisevich, D., Nikolsky, Y. \& Sergeeva, M. G. Drug repositioning through systematic mining of gene coexpression networks in cancer. PLoS ONE 11, 59 (2016).

13. Wishart, D. S. et al. DrugBank 5.0: a major update to the DrugBank database for 2018. Nucleic Acids Res. 46, D1074-D1082 (2018).

14. Draw Venn Diagram. http://bioinformatics.psb.ugent.be/webtools/Venn/.

15. Otasek, D., Morris, J. H., Bouças, J., Pico, A. R. \& Demchak, B. Cytoscape Automation: empowering workflow-based network analysis. Genome Biol. 20, 1-15 (2019).

16. Brickey, W. J. et al. MyD88 provides a protective role in long-term radiation-induced lung injury. Int. J. Radiat. Biol. 88, 335-347 (2012).

17. Floyd, S. R. et al. The Bromodomain protein Brd4 insulates chromatin from DNA damage signaling. Nature 498, 246-250 (2013).

18. Lin, Z.-Z., Chou, C.-H., Cheng, A.-L., Liu, W.-L. \& Chia-Hsien Cheng, J. Radiosensitization by combining an aurora kinase inhibitor with radiotherapy in hepatocellular carcinoma through cell cycle interruption. Int. J. Cancer 135, 492-501 (2014).

19. Sersa, I. et al. Study of radiation induced changes of phosphorus metabolism in mice by 31P NMR spectroscopy. Radiol. Oncol. 44, 174-179 (2010).

20. D’Andrea, F. P. et al. Cancer stem cell overexpression of nicotinamide N-methyltransferase enhances cellular radiation resistance. Radiother. Oncol. 99, 373-378 (2011).

21. Mojena, M. et al. Protection against gamma-radiation injury by protein tyrosine phosphatase 1B. Redox Biol. 17, 213-223 (2018).

22. Ahmed, K. M. \& Li, J. J. NF-kappa B-mediated adaptive resistance to ionizing radiation. Free Radic. Biol. Med. 44, 1-13 (2008).

23. Skvara, H. et al. Mcl-1 blocks radiation-induced apoptosis and inhibits clonogenic cell death. Anticancer Res. 7, 2697-2703 (2005).

24. Han, G. et al. Annexin A1-mediated inhibition of inflammatory cytokines may facilitate the resolution of inflammation in acute radiation-induced lung injury. Oncol. Lett. 18, 321-329 (2019). 
25. Kidd, A. R. et al. The Ras-related small GTPases RalA and RalB regulate cellular survival after ionizing radiation. Int. J. Radiat. Oncol. Biol. Phys. 78, 205-212 (2010).

26. Malik, N. et al. The transcription factor CBFB suppresses breast cancer through orchestrating translation and transcription. Nat. Commun. 10, 1-15 (2019).

27. Wang, C.-Y. \& Lin, C.-F. Annexin A2: Its Molecular Regulation and Cellular Expression in Cancer Development. Dis. Markers https://doi.org/10.1155/2014/308976 (2014).

28. Yamaguchi, M. et al. The thrombopoietin mimetic romiplostim leads to the complete rescue of mice exposed to lethal ionizing radiation. Sci. Rep. 8, 1-12 (2018).

29. Russo, A. A., Jeffrey, P. D., Patten, A. K., Massagué, J. \& Pavletich, N. P. Crystal structure of the p27Kip1 cyclin-dependent-kinase inhibitor bound to the cyclin A-Cdk2 complex. Nature 382, 325-331 (1996).

30. Kuerbitz, S. J., Plunkett, B. S., Walsh, W. V. \& Kastan, M. B. Wild-type p53 is a cell cycle checkpoint determinant following irradiation. Proc. Natl. Acad. Sci. U. S. A. 89, 7491-7495 (1992).

31. Peterson, J. A., Maroney, S. A. \& Mast, A. E. Targeting TFPI for hemophilia treatment. Thromb. Res. 141(Suppl 2), S28-30 (2016).

32. Kennedy, A. R., Maity, A. \& Sanzari, J. K. A review of radiation-induced coagulopathy and new findings to support potential prevention strategies and treatments. Radiat. Res. 186, 121-140 (2016).

33. Davis, T. A. et al. Timing of captopril administration determines radiation protection or radiation sensitization in a murine model of total body irradiation. Exp. Hematol. 38, 270-281 (2010).

34. Valenciano, A., Henríquez-Hernández, L. A., Moreno, M., Lloret, M. \& Lara, P. C. Role of IGF-1 receptor in radiation response. Transl. Oncol. 5, 1-9 (2012).

35. Yun, M. et al. Carbonyl reductase 1 is a new target to improve the effect of radiotherapy on head and neck squamous cell carcinoma. J. Exp. Clin. Cancer Res. CR 37, 264 (2018).

36. Chinn, I. K. et al. Novel combined immune deficiency and radiation sensitivity blended phenotype in an adult with biallelic variations in ZAP70 and RNF168. Front. Immunol. 8, 576-576 (2017).

37. Grossman, S. A. et al. Survival in patients with severe lymphopenia following treatment with radiation and chemotherapy for newly diagnosed solid tumors. J. Natl. Compr. Cancer Netw. JNCCN 13, 1225-1231 (2015).

38. Wang, J.-T. et al. NADH protect against radiation enteritis by enhancing autophagy and inhibiting inflammation through PI3K/ AKT pathway. Am. J. Transl. Res. 10, 1713-1721 (2018).

39. Apweiler, R. et al. UniProt: the universal protein knowledgebase. Nucleic Acids Res. 45, D158-D169 (2017).

40. Lee, K.-F. et al. Gene expression profiling of biological pathway alterations by radiation exposure. BioMed Res. Int. https://doi. org/10.1155/2014/834087 (2014).

41. Verheij, M. \& Bartelink, H. Radiation-induced apoptosis. Cell Tissue Res. 301, 133-142 (2000).

42. Giannandrea, M. \& Parks, W. C. Diverse functions of matrix metalloproteinases during fibrosis. Dis. Model. Mech. 7, 193-203 (2014).

43. Straub, J. M. et al. Radiation-induced fibrosis: mechanisms and implications for therapy. J. Cancer Res. Clin. Oncol. 141, 1985-1994 (2015).

44. Wang, H. et al. ZAP-70: an essential kinase in T-cell signaling. Cold Spring Harb. Perspect. Biol. 2, a002279 (2010).

45. Aryankalayil, M. J. et al. Radiation-induced long noncoding RNAs in a mouse model after whole-body irradiation. Radiat. Res. 189, 251-263 (2018).

46. Meadows, S. K. et al. Gene expression signatures of radiation response are specific, durable and accurate in mice and humans. PLoS ONE 3, e1912 (2008).

47. Dressman, H. K. et al. Gene expression signatures that predict radiation exposure in mice and humans. PLoS Med. 4, e106 (2007).

48. Clough, E. \& Barrett, T. The Gene Expression Omnibus database. Methods Mol. Biol. Clifton NJ 1418, 93-110 (2016).

49. Ritchie, M. E. et al. limma powers differential expression analyses for RNA-sequencing and microarray studies. Nucleic Acids Res. 43, e47 (2015).

50. Gautier, L., Cope, L., Bolstad, B. M. \& Irizarry, R. A. affy-analysis of Affymetrix GeneChip data at the probe level. Bioinform. Oxf. Engl. 20, 307-315 (2004).

51. Corsello, S. M. et al. The Drug Repurposing Hub: a next-generation drug library and information resource. Nat. Med. 23, 405-408 (2017).

52. Subramanian, A. et al. A Next Generation Connectivity Map: L1000 platform and the first 1,000,000 profiles. Cell 171, 1437-1452. e17 (2017).

53. Amberger, J. S. \& Hamosh, A. Searching Online Mendelian Inheritance in Man (OMIM): a knowledgebase of human genes and genetic phenotypes. Curr. Protoc. Bioinforma. 58, 1.2.1-1.2.12 (2017).

54. Resource, T. G. O. 20 years and still GOing strong. Nucleic Acids Res. 47, D330-D338 (2019).

55. Kanehisa, M., Sato, Y., Kawashima, M., Furumichi, M. \& Tanabe, M. KEGG as a reference resource for gene and protein annotation. Nucleic Acids Res. 44, D457-D462 (2016).

56. Fabregat, A. et al. The reactome pathway knowledgebase. Nucleic Acids Res. 46, D649-D655 (2018).

57. Jeremy A. Miller's and Peter Langfelder's Enrichment Functions. https://horvath.genetics.ucla.edu/html/CoexpressionNetwork/ GeneAnnotation/.

58. Huang, D. W., Sherman, B. T. \& Lempicki, R. A. Systematic and integrative analysis of large gene lists using DAVID bioinformatics resources. Nat. Protoc. 4, 44-57 (2009).

59. Szklarczyk, D. et al. STRING v11: protein-protein association networks with increased coverage, supporting functional discovery in genome-wide experimental datasets. Nucleic Acids Res. 47, D607-D613 (2019).

\section{Acknowledgements}

This material is based upon work supported by the Defense Health Agency and U.S. Strategic Command under Contract No. FA4600-12-D-9000. Any opinions, findings and conclusions or recommendations expressed in this material are those of the author(s) and do not necessarily reflect the views of the Defense Health Agency, U.S. Strategic Command, or 55th Contracting Squadron.

\section{Author contributions}

T.H., B.L.P., D.B., and K.W.B. conceived the study. T.H. and B.L.P. designed and directed the study. R.M. and B.L.P. collected and analyzed data. R.M., B.L.P., and T.H. wrote the manuscript. R.P., C.G., D.B., and K.W.B. provided feedback throughout the study.

\section{Funding}

This study was supported by an NIH grant \#1R35GM119770 to T.H. 


\section{Competing interests}

The authors declare no competing interests.

\section{Additional information}

Supplementary Information The online version contains supplementary material available at https:/doi. org/10.1038/s41598-021-85044-5.

Correspondence and requests for materials should be addressed to T.H.

Reprints and permissions information is available at www.nature.com/reprints.

Publisher's note Springer Nature remains neutral with regard to jurisdictional claims in published maps and institutional affiliations.

(c) (1) Open Access This article is licensed under a Creative Commons Attribution 4.0 International License, which permits use, sharing, adaptation, distribution and reproduction in any medium or format, as long as you give appropriate credit to the original author(s) and the source, provide a link to the Creative Commons licence, and indicate if changes were made. The images or other third party material in this article are included in the article's Creative Commons licence, unless indicated otherwise in a credit line to the material. If material is not included in the article's Creative Commons licence and your intended use is not permitted by statutory regulation or exceeds the permitted use, you will need to obtain permission directly from the copyright holder. To view a copy of this licence, visit http://creativecommons.org/licenses/by/4.0/.

(C) The Author(s) 2021 